\title{
Decapitation and Dynamite: The Mutilated Mountainside Monument of Gaius Julius Aquila on the Coast of Bithynia et Pontus
}

\author{
Sean Silvia
}

\begin{abstract}
The Roman monument locally known as Kuskayast Yol Antt (literally bird rock road monument) in Turkish is an arresting site carved in relief on a mountainside. Its decapitated figures have hewn limbs, and dynamite has blasted out large chunks of the monument. Though scholars have tangentially touched upon Kuskayasi, there is little analysis of its visual symbolism and the mutilated buman figure's identity and destruction have been mysteries. This paper will analyse the monument and explicate its noteworthy blend of Roman Imperial and local iconography, a syncretistic design which participates in the Romanization of Bithynia et Pontus and legitimizes the monument's builder Gaius Julius Aquila. Next, this paper will argue that the mysterious beheaded figure likely represents Aquila rather than Emperor Claudius. Finally, this paper will forward that Kuskayast was the victim of Christian mutilation in Late Antiquity during its initial phase of destruction, and treasure hunters in its most recent phase. Kuskayast represents an innovative symbolic composition and speaks both to the syncretistic public art tradition and the history of the destruction of antiquities on the Black. Sea coast.
\end{abstract}

Keywords: Kuskayası, rock reliefs, Black Sea coast, Roman sculpture, destruction of monuments

Kuskayası Yol Anıtı (literally bird rock road monument in Turkish) is a striking Roman monument carved in relief into the mountainside along an ancient road on the Black Sea coast of northern Anatolia (Fig. 1). ${ }^{1}$ Gaius Julius Aquila, who built the monument, was

\footnotetext{
* My gratitude goes to John Pollini, endowed professor in Art History at the University of Southern California, who read my manuscript and provided me with valuable information and photographs. I am also grateful to Christian Marek, emeritus professor of Ancient History at the University of Zurich, for his helpful correspondence, information and photographs. Finally, I would like to thank Alessandra Schultz for pointing me in the direction of the Claudian apotheosis cameo.
} 


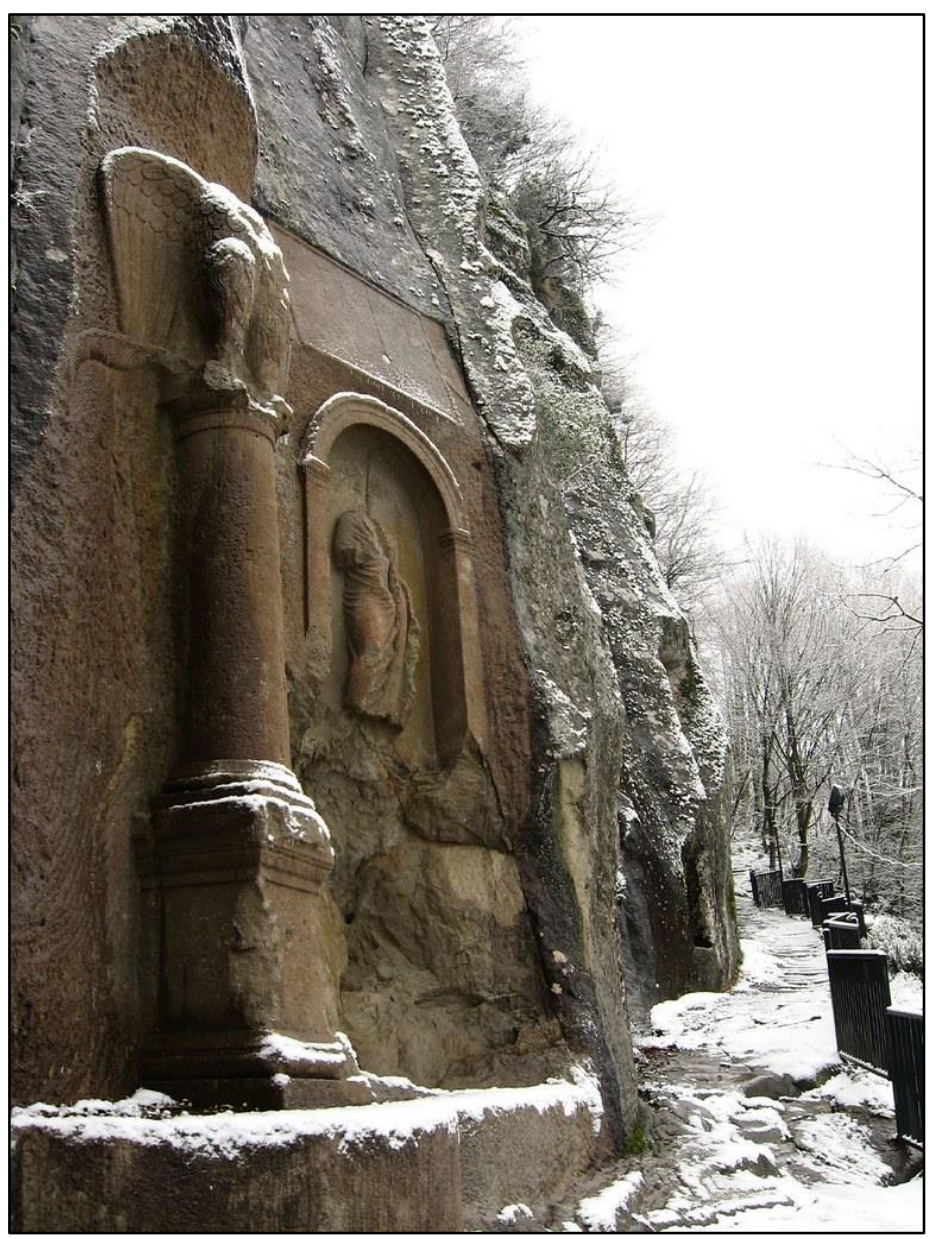

Fig. 1 Bird's Rock Roman Road Monument near Amasra, Turkey. Photograph: Robert Thomson, Creative Commons BY-NC 2.0 license.

the permanent High Priest of Divus Augustus (perpetuus Sacerdos Divi Augusti). ${ }^{2}$ Many different scholars have tangentially touched upon the monument, but Chingyuan Wu has written the most thorough treatment of the monument to date. ${ }^{3} \mathrm{Wu}$ provides an

${ }^{1}$ The monument has no official Latin or Greek name, and will be referred to by its local Turkish name.

${ }^{2}$ Wu 2018, 63.

3 Wu 2018. For other mentions of the monument see Alper \& Alper 2010, 323; the following fieldwork reports from scholars studying Amasra (ancient Amastris) indicate Kuskayası and the surrounding roads as profitable areas for future research, but do not engage in it themselves, Eyice 1955, 109-112; Eyice 1965, 21; Richard et al. 1976, 47; Blaylock et al. 1990; Blaylock et al. 1991; 


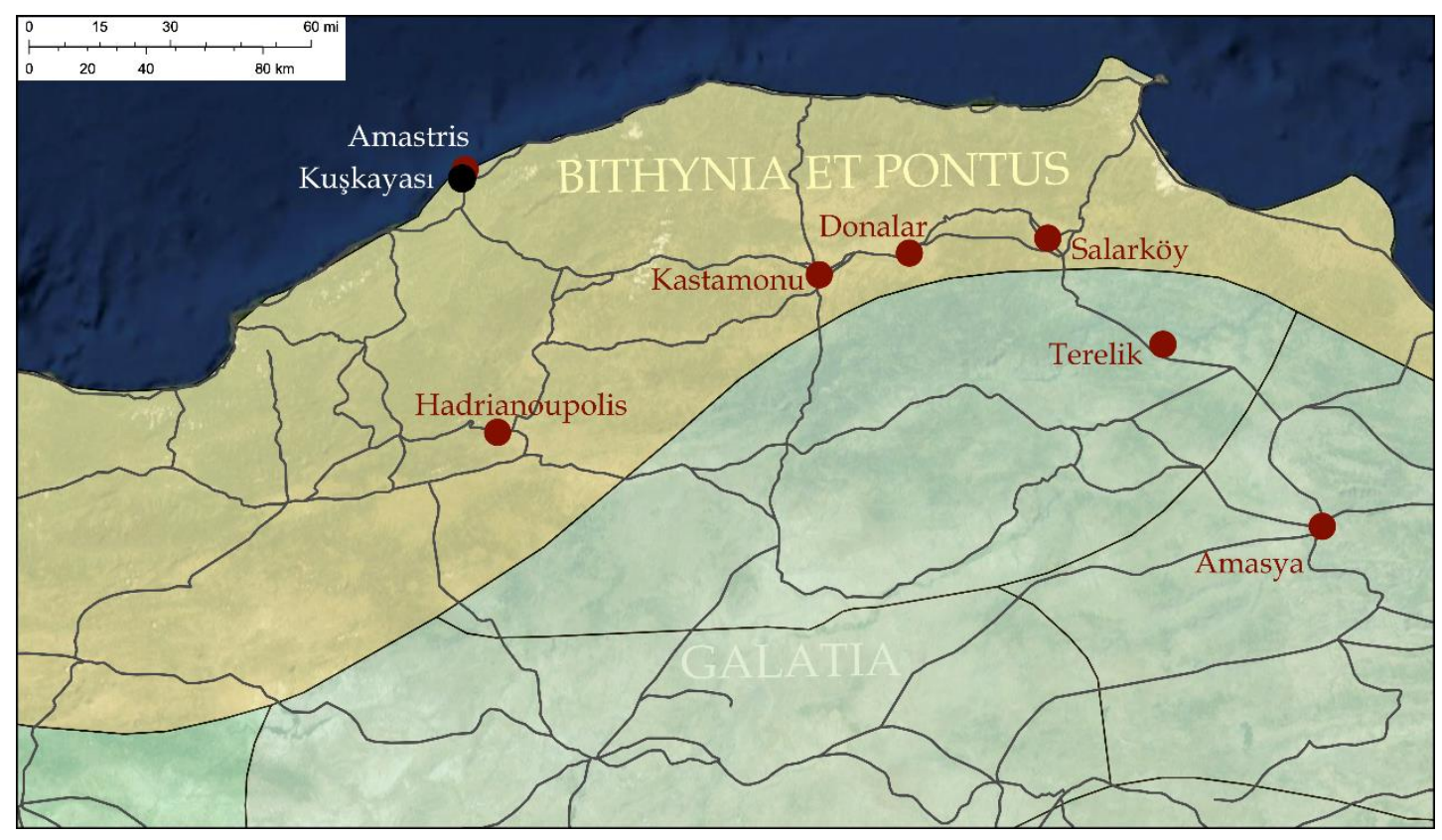

Fig. 2 A map of Roman Paphlagonia in the first century CE. Digital Atlas of Roman and Medieval Civilizations and Author, Creative Commons BY-NC-SA 4.0 license.

overview of the monument's elements focusing on their religious import for the cult of Divus Augustus, and discusses the site's evidence of Aquila's priesthood, and whether it was a position of regional significance. This paper will add to Wu's study with a visual analysis of the monument's blend of local and imperial styles, and it will argue that this represents an attempt to reach a local audience in Paphlagonia. Aquila added his own imagery to a collage of cults and visuals, using them to promote himself. As the monument's surviving inscriptions begin with dedications to Claudius but celebrate Aquila as a priest, praefectus fabrum, and the builder of the road, the identity of the headless bimation-wearing figure in the niche has been uncertain: is it Emperor Claudius or Aquila? Scholars have not yet fully addressed this question, and this paper will use the figure's clothing, symbolism and relations to the other elements of the monument to argue that it represents Aquila rather than Claudius. Finally, this paper will theorize that the monument's recent destruction was the result of treasure hunters, and that its earlier destruction was the result of Late Antique Christian mutilation.

French et al. 1992; Marek 1993, Marek 2003; Çorumluoğlu et al. 2013, Çorumluoğlu et al. 2014; Çam et al. 2019. 


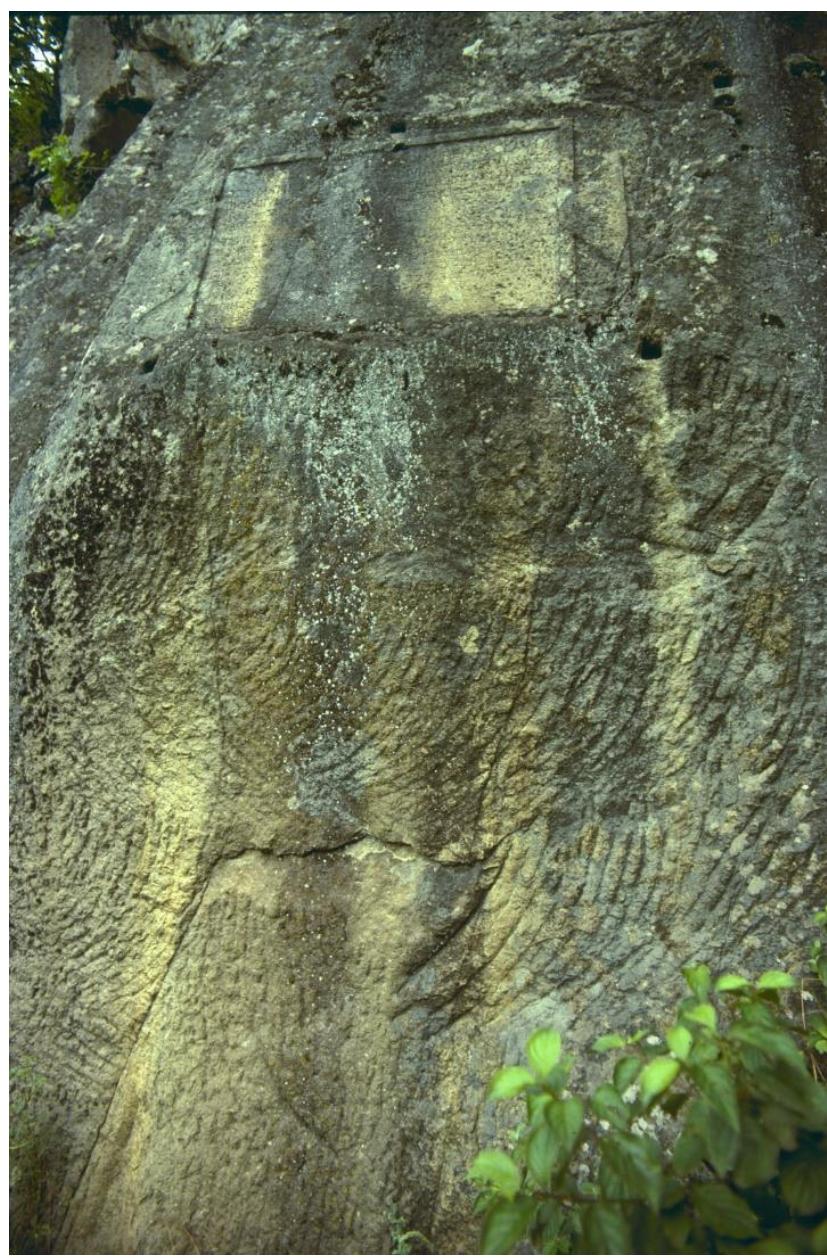

Fig. 3 View of the western tabula, surrounded by 4 post holes. Photograph: courtesy of Christian Marek.

\section{Composition and condition of the monument}

Kuşkayas1 is located in the ancient province of Bithynia et Pontus on the road that ran from Tieion to Sinope, approximately $4 \mathrm{~km}$ southwest of the ancient city of Amastris on the Black Sea coast (Fig. 2). The monument lies c. 360 m.a.s.l. ${ }^{4}$ It was hewn out of the natural volcanic andesite/dacite rock of the cliff face, and chisel marks are readily apparent along the mountain-cut road and around the monument itself. ${ }^{5}$

4 Marek 2003, 109.

5 Tokay 1962, 8, 23. 


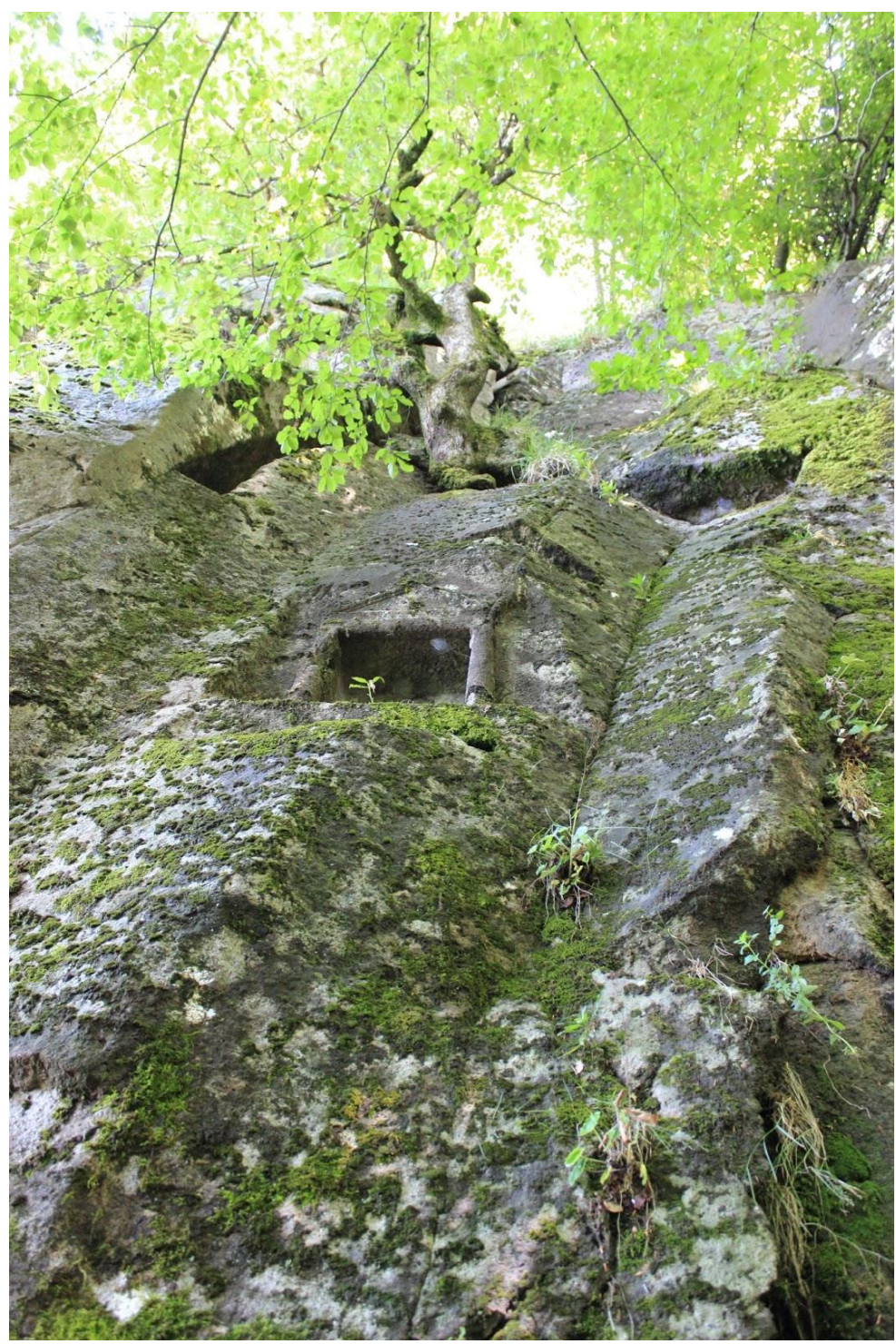

Fig. 4 Amasra Kuşkayası Yol Anıtı. zsmile, Adobe Stock Standard License.

The westernmost part of the monument features a bilingual tabula ansata, which is carved in low relief high up on the cliff side (Fig. 3, inscription text below). ${ }^{6}$ Slightly above this tabula and to the right is a miniature temple (naiskos) carved into the rock, with a triangular pediment supported by two columns (Fig. 4). It is possible that like with aediculae at Pompeii (Fig. 5), there were painted depictions of a deity or deities on the back wall of the naiskos, or like a similar niche at nearby Hadrianoupolis there were

${ }^{6}$ Marek 1993, 92. 


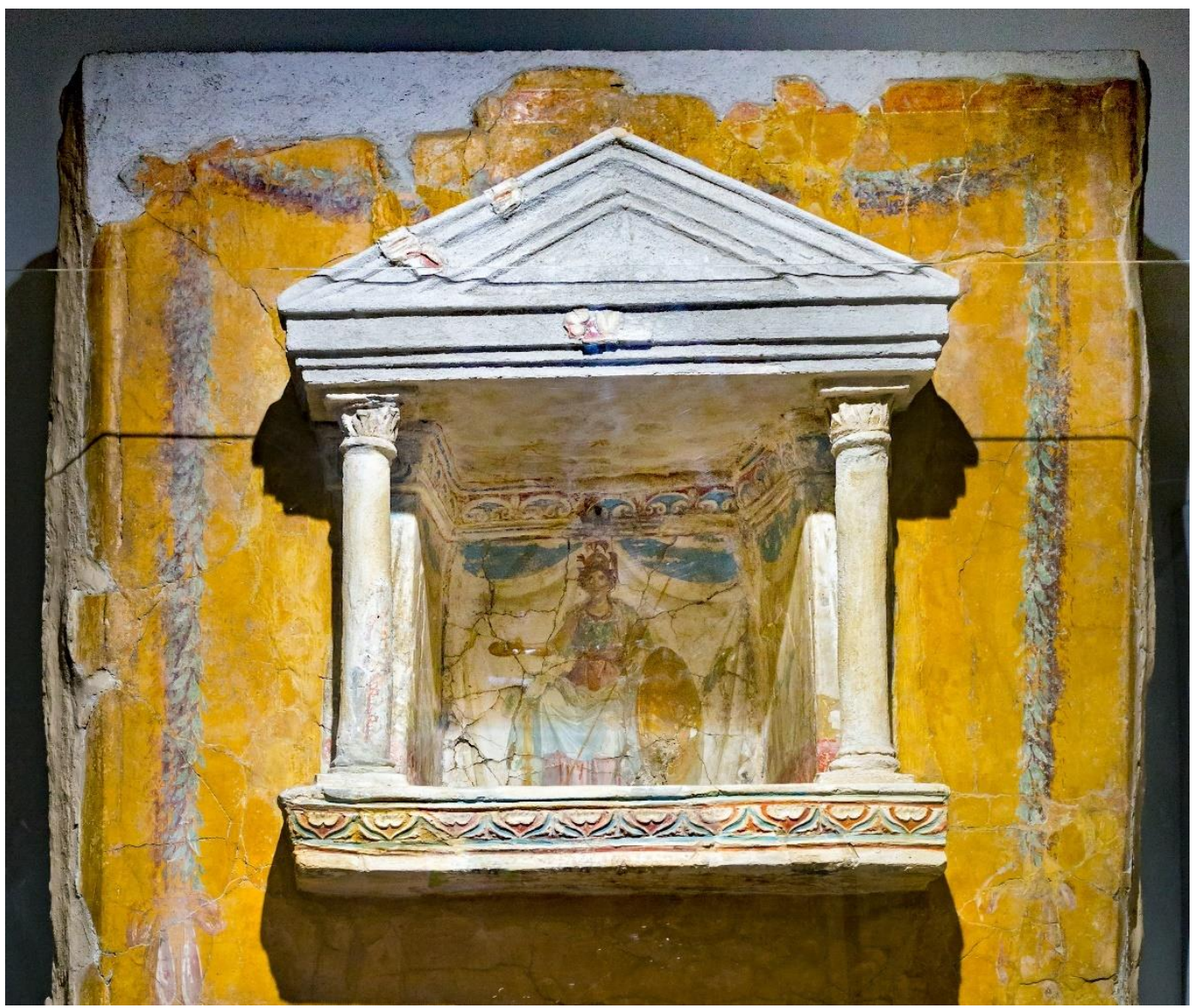

Fig. 5 Wall painting - Athena in aedicula and snake at altar - Gragnano Carmiano (villa A). ArchaiOptix, Creative Commons A-SA 4.0 License.

portable figures placed inside. ${ }^{7}$ There are four extant post holes around the tabula, which may have supported a wooden roof to go above the inscription relief or some other wooden structure, although how this would have functioned is uncertain. ${ }^{8}$ Its inscription labels it as a sessionem (seating place) and indeed there are seating areas carved into the cliff face along the road next to the monument (Fig. O). The roadway leading to this section of the monument is, like the rest of this section of roadway, paved with stones.

${ }^{7}$ Laflı 2007, 59; Wu 2018, 73, 74. It is possible these figures could be the emperor alongside principal patron deities of Amastris: Zeus Strategos and Hera. They might also connect to the administration of an imperial oath, such as the Oath of Gangra through which one declared loyalty to the emperor. In that case the deities might be Zeus, Ge and Helios.

${ }^{8}$ Marek 1993, 92. 


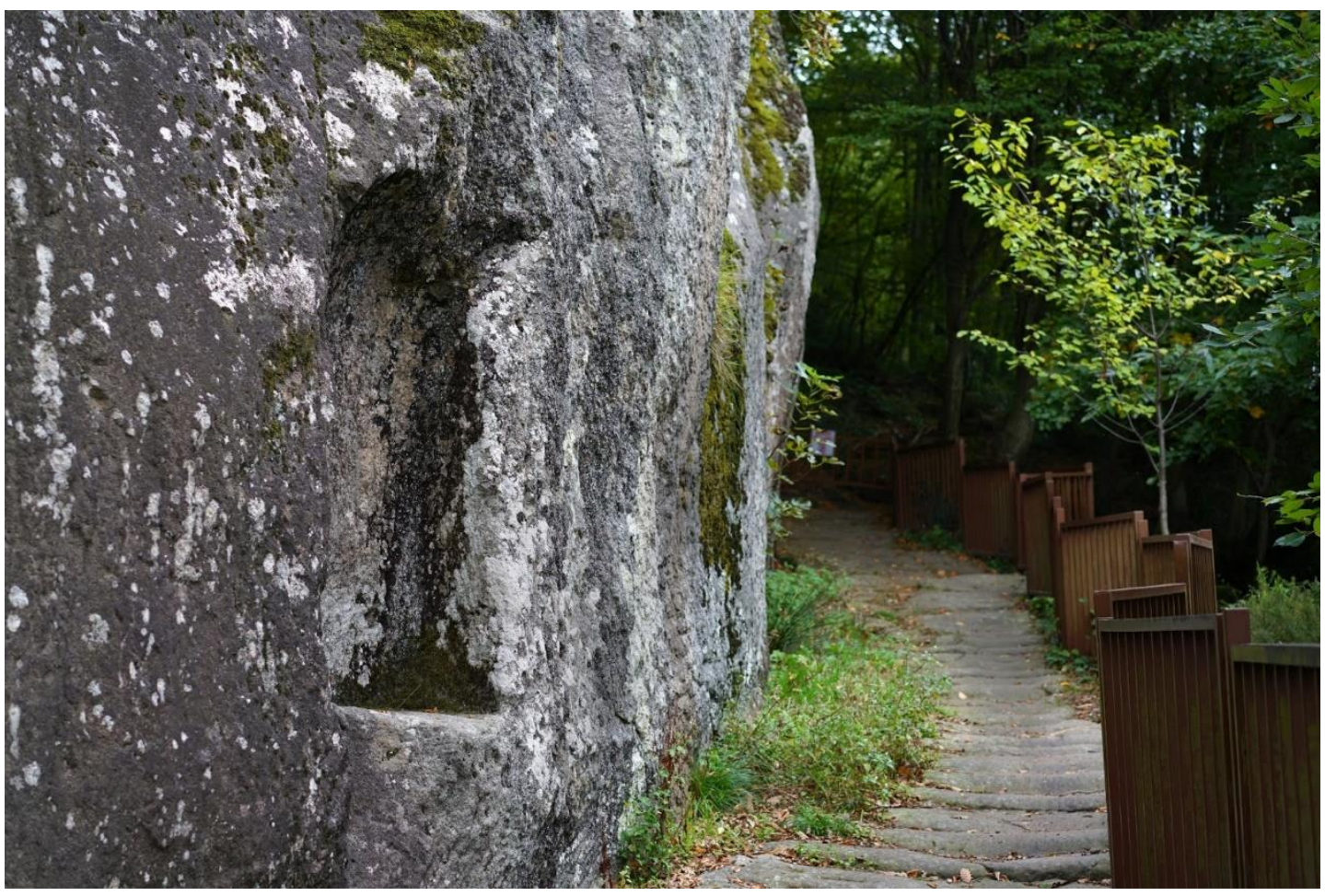

Fig. 6 One of the cliff-carved sitting areas. The Roman monument (Kuşkayasi) for the road at Amasra, Turkey. Selcuk, Adobe Stock Standard License.

\section{Western tabula ansata text:}

Pro pace au[gusti] in honorem Ti(berii) Claudi

Germanici [Caesaris Aug.] Divi Aug. perpetuus sacer

dos $\mathrm{G}$ (aius) Ivlivs [Aquila pr]aef(ectus) fabr(um) bis in aerar(ium) delatus

a co(n)s(ulibus) A(ulo) Gabin[i]o [Secundo Ta] uro Statilio Corvino mon

tem cecidit e[t viam - - - et s]essionem d(e) s(ua) p(ecunia) $\mathrm{f}($ ecit $)$

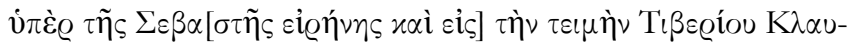

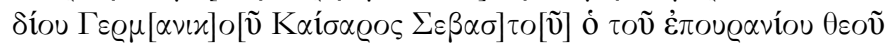

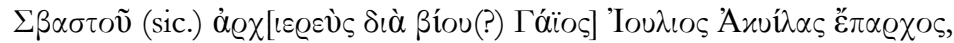

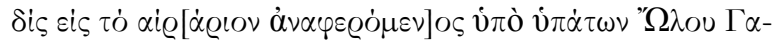

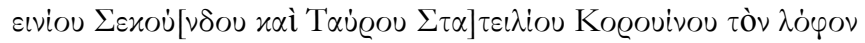

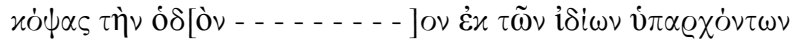

$\dot{\varepsilon} \pi \circ i \eta \emptyset \varepsilon v^{9}$

${ }^{9}$ Dessau 1979, 445-446. Also ILS $5883=$ IGR iii $83=$ Katalog der Inschriften von Amastris 1b (cf. 1a) in Marek 1993 = JÖAI 28 (1933) Beibl. 64.13. 


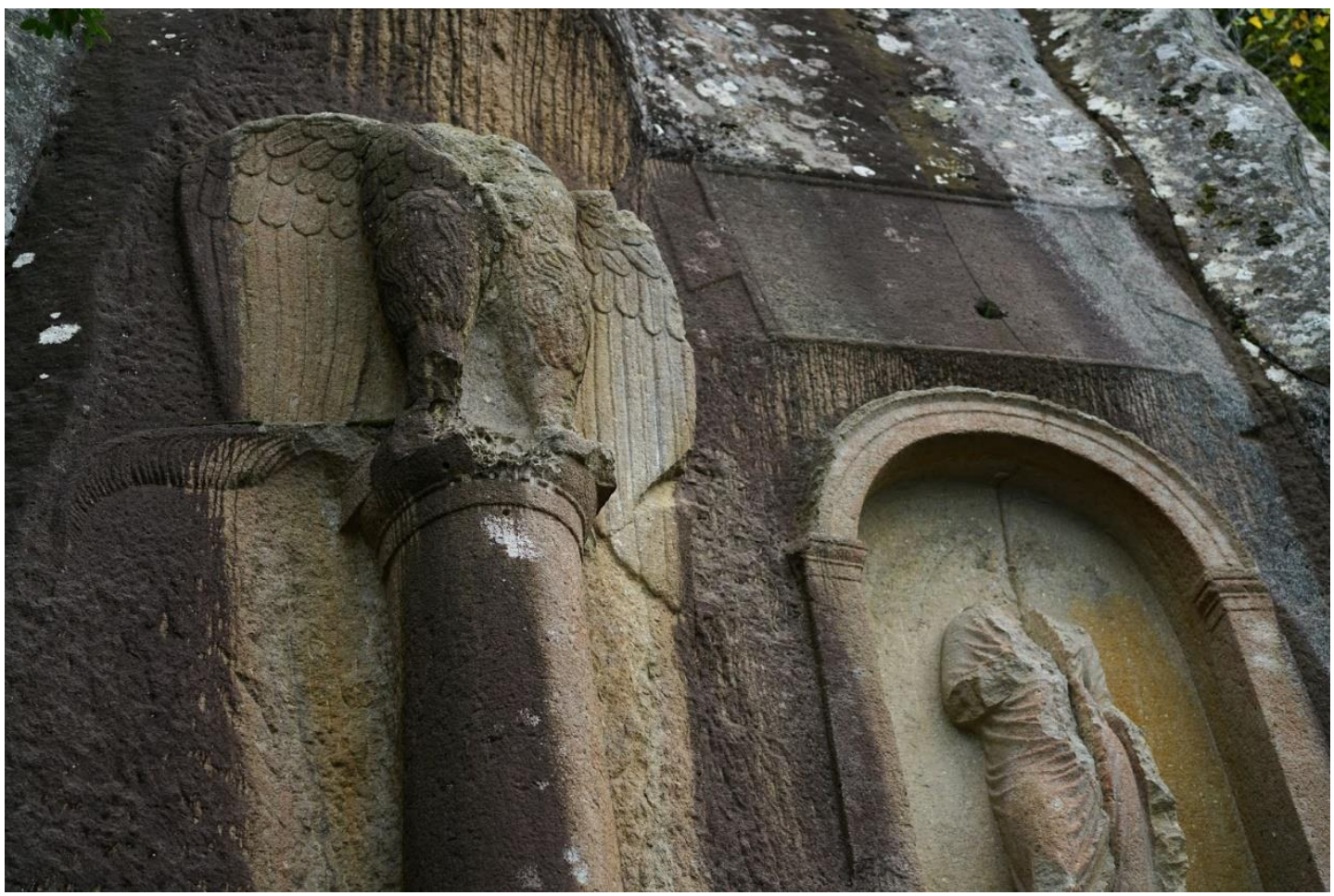

Fig. 7 The upper part of the eastern portion of the monument. The Roman monument (Kuşkayası) for the road at Amasra, Turkey. Selcuk, Adobe Stock Standard License.

On account of Augustan peace (and) in honor of Tiberius Claudius Germanicus Caesar Augustus, the permanent (high)-priest of (Epouranios) Divus Augustus, Gaius Iulius Aquila, registered twice at the aerarium as praefectus fabrum by the consuls Aelius Gabinius Secundus (then) Taurus Statilius Corvinus, cut through the mountain and (paved?) the road, made this at his own expense. ${ }^{10}$

The eastern portion of the monument features a niche that stands around $260 \mathrm{~cm}$ tall and $200 \mathrm{~cm}$ wide, the column shaft at about the same height as the niche, and an eagle and a human figure each c. $185 \mathrm{~cm}$ tall. ${ }^{11}$ The niche is a smooth round arch supported by pilasters and framed by a squared-off and flattened cliff face around it. It features the remains of a life-size human figure wearing a himation carved in relief from the smoothed backdrop of the niche. ${ }^{12}$ There is a hole drilled into the rock above the

\footnotetext{
${ }^{10}$ Wu 2018, 63-64. Text and translation from Wu with slight modifications by author.

11 Marek 2003, 109.

12 Marek 2003, 56.
} 


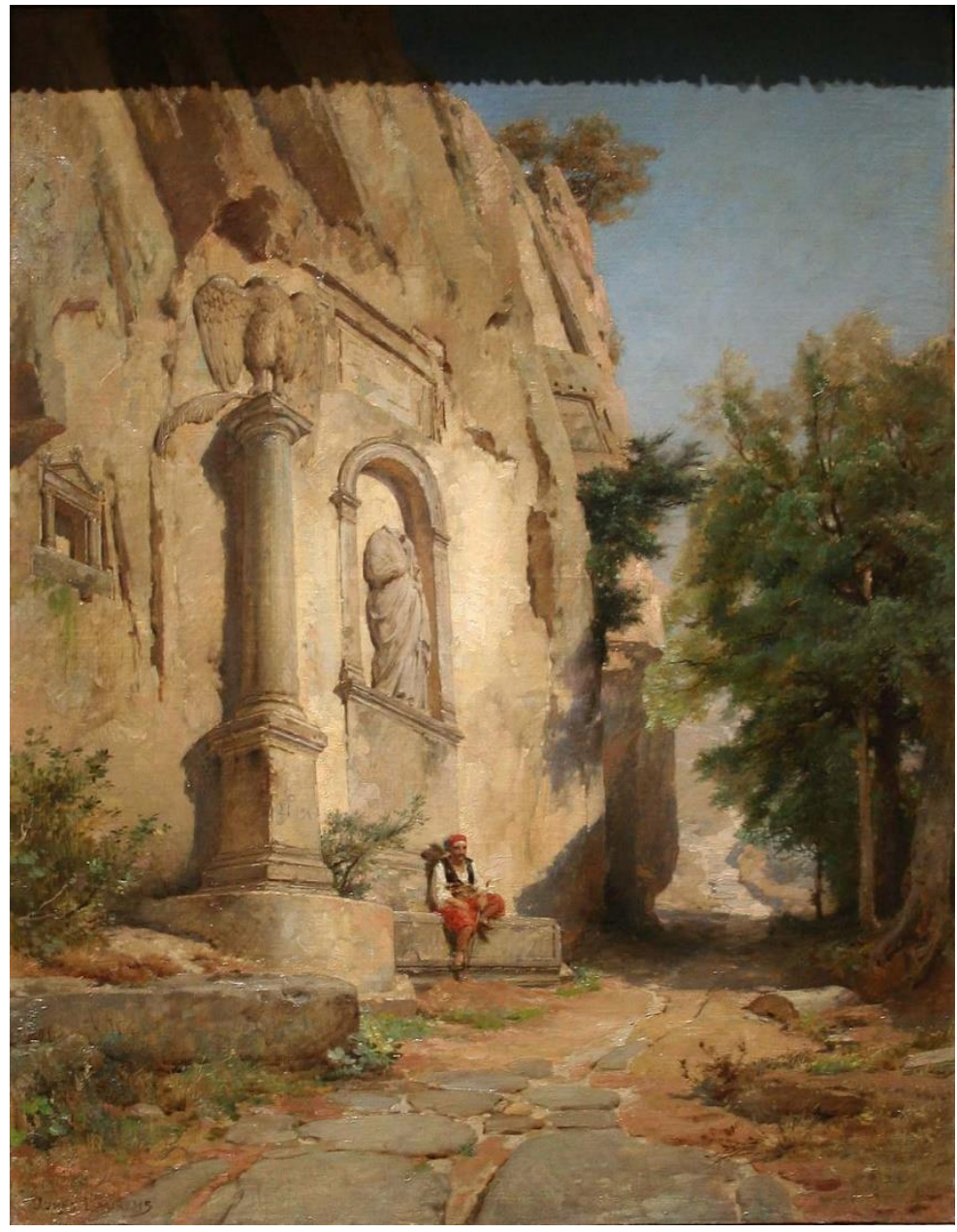

Fig. 8 Jules Laurens, Tête de voie romaine, 1846. This painting takes some liberties with the monument, including placing the western tabula ansata on the right in a different location so that it can be seen from this angle, and moving the small naiskos to the left for the same reason. Public domain.

shoulders, which indicates that the head was installed separately (Fig. 7). ${ }^{13}$ A low relief pedestal used to stand under the niche before it was destroyed by dynamite. At the foot of the former pedestal lies a flattened protruding surface with a curvilinear section beginning at the base of the column, which is the right height to serve as a sitting area. To the left of the niche a column stands on a pedestal and supports a perched eagle with

${ }^{13} \mathrm{Wu} 2018,68$. 
outstretched wings. The eagle's talons clutch a stylized palm branch carved in low relief against the cliff. Traces of a dedicatory inscription to Theos Hypsistos Helios appear on the pedestal. ${ }^{14}$

At the top of the eastern part of the monument the worked cliffside forms a flattened plane that tilts back at a slight angle, bearing an inscribed tabula ansata only some of which remains legible. Though they begin the same way, the texts of the two tabulae are different as the tabula above the niche is wholly in Greek; one can make out a sigma and a lambda in the bottom third of the heavily eroded text. It features a longer dedication message than the eastern tabula. This indicates that the monument is in two parts, a western section and an eastern section, with two separate dedications. Aquila likely commissioned these at two different times across his tenure as perpetuus sacerdos. ${ }^{15}$

Legible portion of the eastern tabula ansata text:

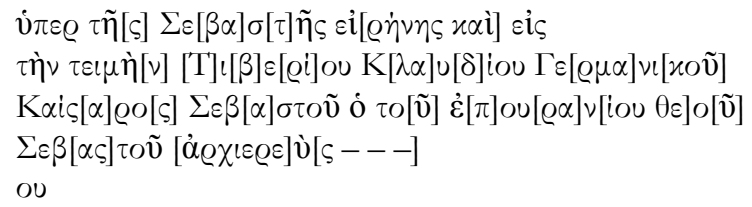

On account of Augustan peace (and) in honour of Tiberius Claudius Germanicus Caesar Augustus, the high-priest of Epouranios Divus Augustus

Kuşkayası has seen a significant amount of damage over the years. Firstly, both the eagle and the human figure have been beheaded, and the human figure's feet and hands were likewise destroyed. Additionally, there is the large, rough hollow which used to be the niche's pedestal; the dynamite drill holes which riddle this section of the monument make it all too clear what caused this damage. The hollow extends up to the lower section of the niche and bottom part of the left pilaster, both of which are completely destroyed. A large crack also runs from this hollow up through the human figure and continues onto the back of the niche above. There are boreholes covering Kuşkayas1 including the bottom of the column and the tabula ansata above the human figure. There are no traces of paint left. One can often see staining drip marks running down the monument caused by rainfall runoff from the side of the mountain, and sometimes growth of moss. Finally, damage from erosion is evident especially in the nearly erased text of the tabula ansata over the niche.

$14 \mathrm{Wu} 2018,72-73$.

$15 \mathrm{Wu} 2018,69-71$. 


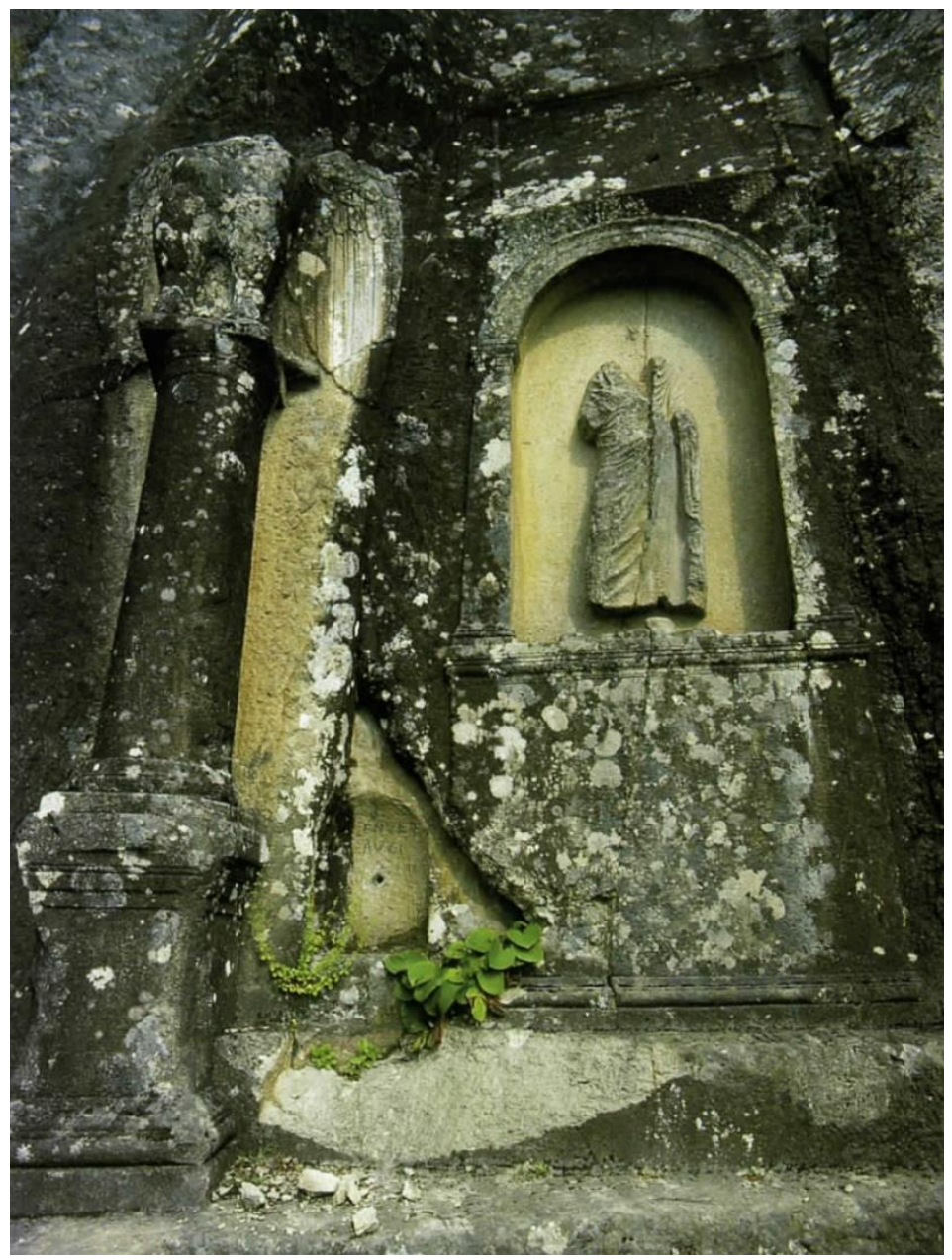

Fig. 9 Courtesy of Marek, from Pontus et Bithynia, p. 48. Note the then-minimal damage to the niche pedestal.

\section{Dating Kuşkayasi}

The western inscription identifies Aquila as being made a praefectus fabrum, an equestrian position, by Aulus Gabinius Secundus (in $44 \mathrm{CE}$ ) and Taurus Statilius Corvinus (in 45 CE) which provides a terminus post quem of $45 \mathrm{CE} .{ }^{16}$ According to Tacitus' Annales, in 49 CE Aquila was dispatched to the Black Sea region to support King Tiberius Julius Cotys I, in command of a few battalions. He reports that Aquila carried out a successful campaign against the recently deposed Mithridates and his allies. For his service he

16 Wu 2018, 75-76. 


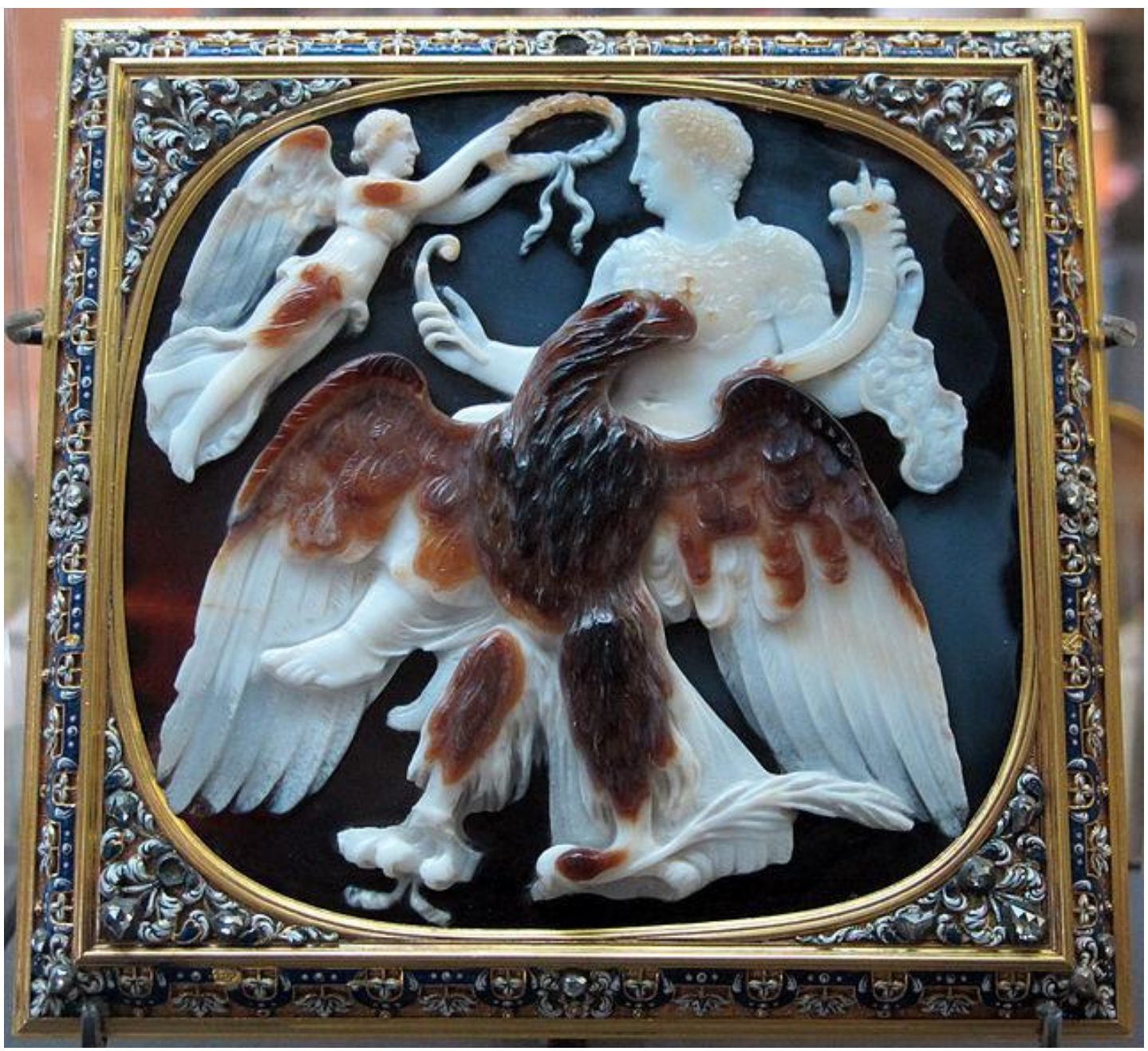

Fig. 10 Apotheosis of Claudius Cameo. Sailko, Creative Commons A-SA 3.0 License.

earned the praetorian insignia. ${ }^{17}$ Had Aquila held the praetorian insignia when he dedicated the western inscription, he would almost certainly have mentioned this noteworthy accomplishment. The fact that a reference to the praetorian insignia is absent from the inscription suggests this part of the monument dates from 45-49 CE.

The eastern portion of the monument with its longer Greek inscription likely came later. The letters that begin line five (the only letters legible in the line) are an

17 Tac., Ann. 7.17.22. 
omicron followed by an upsilon and they are in position to come directly after Aquila's name. This indicates that the text starts to differ between the two inscriptions right after Aquila is introduced, because in the western inscription there are no sequences with an omicron followed by an upsilon until viò vi $\pi \alpha ́ \tau \omega \nu$ six words after Aquila's name. Something else is there in the eastern inscription instead of or before the mention of Aquila's position as a praefectus fabrum, perhaps new honours such as the praetorian insignia he earned in $49 \mathrm{CE}$. In this part of the monument, the eagle may in part act as a symbol of the Roman state and legion guaranteeing the Pax Augusta on a monumentalized road which facilitated the movement of Roman troops. This victorious iconography supports a date following Aquila's successful military campaign in 49 CE. This second phase of the monument had to come before the end of Claudius' reign in 54 because it refers to him by name in the dedication, giving it a tentative date of 49-54 CE.

The decapitations and the destruction of the human figure's hands and feet are more difficult to date, with a terminus ante quem of 1846 when traveller Jules Laurens painted the by-then-mutilated monument (Fig. 8). A Late Antique date will be proposed in the last section of this article based on the targeted nature of the initial stage of damage and a cross carved into the column. The most recent major phase of destruction, caused largely by dynamite and targeting the niche's pedestal, has a terminus post quem in Marek's 1986 photograph of the monument from Pontus et Bithynia: Die römischen Provinzen im Norden Kleinasiens (Fig. 9). ${ }^{18}$ In the photograph Kuşkayas1 already shows some early destruction, with a borehole and hollow, and a small chunk missing from the front of the niche's pedestal. Some rubble still lies on the ground beneath it, suggesting that this destruction was relatively recent when the photo was taken. The crack running down the centre of the niche had also already formed by this date.

\section{Appeal to a local audience through syncretistic design}

Wu details how 'Aquila created a collage of local and imperial cults' including Divus Augustus and Theos Hypsistos Helios, which he intentionally selected to 'attract a broader audience in coastal Paphlagonia'. ${ }^{19}$ Aquila parallels this collage of cults with

${ }^{18}$ I thank Christian Marek for providing the date of his photograph in personal correspondence on 6 November 2020.

${ }^{19} \mathrm{Wu} 2018,88$. 


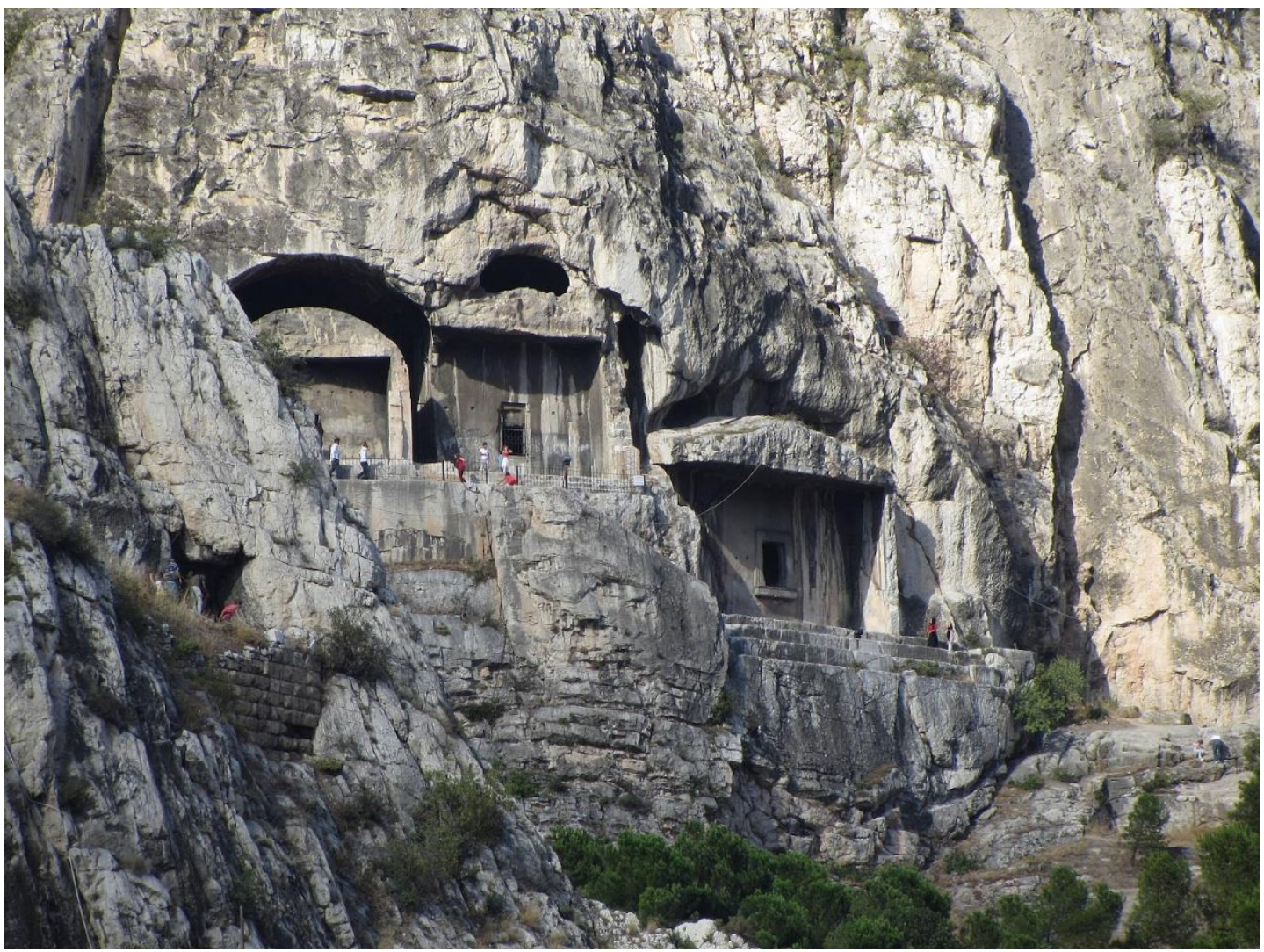

Fig. 11 Third to second century BCE tombs of Pontic kings near Amasya in Northern Anatolia. Photograph: Michael F. Schönitzer, Creative Commons BY-SA 4.0 License.

visual imagery that also blends local and imperial imagery to reach his audience in Paphlagonia, and to give him and his monument legitimacy.

Kuşkayası's column with the eagle perched on its capital takes on multivalent significance that weaves Divus Augustus, Theos Hypsistos Helios and Aquila together. The palm which the eagle clutches in its right talon bears a strong similarity to the eaglecarried palm in the Apotheosis of Claudius Cameo (Fig. 10), a symbol of victory, immortality and the imperial cult. ${ }^{20}$ The palm also potentially invokes the solar aspects of imperial cult theology, which overlap with imagery of the cult of Helios. Eagles

${ }^{20}$ Pollini 2012, 283, 303. 


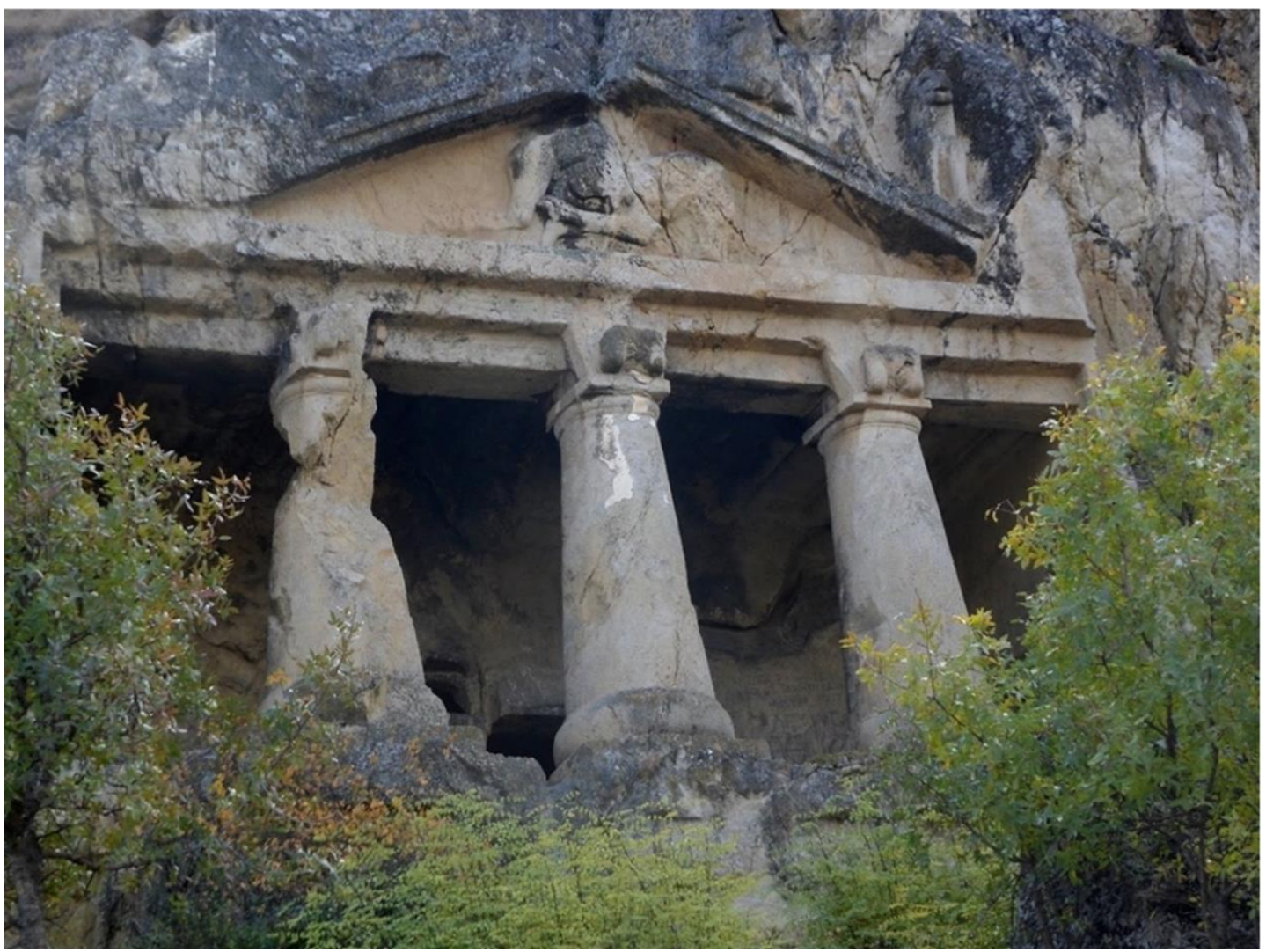

Fig. 12 View of Salar Köyü Kaya Mezarlığı. 'Salar'. Photograph: Kenan Hazar, Creative Commons CC0 1.0 Public Domain Dedication.

frequently appeared alongside dedications to Theos Hypsistos as they do at Kuşkayas1. ${ }^{21}$ In addition to these overlapping deities, the elevated eagle at the top of a smooth, polelike column resembles a Roman eagle standard, invoking the presence of the Roman military. The column is also reminiscent of the honorific columns of the Roman Forum, as a freestanding column elevated on a pedestal with a statue at the top. ${ }^{22}$ Aquila's name means eagle in Latin, and so the placement of an aquila (eagle) at the top of the column acts as a visual pun. It may suggest the idea of Aquila himself standing atop an honorific

${ }^{21} \mathrm{Wu} 2018,72$.

${ }^{22}$ It is possible that the pedestal base of the column took on some significance as an altar, or evoked the idea of an altar, though there is evidence suggesting a pure architectural function at sites like Aphrodisias and in later literature. Either way, this feature elevated the column in a literal if not also symbolic function; Coulton 2005. 


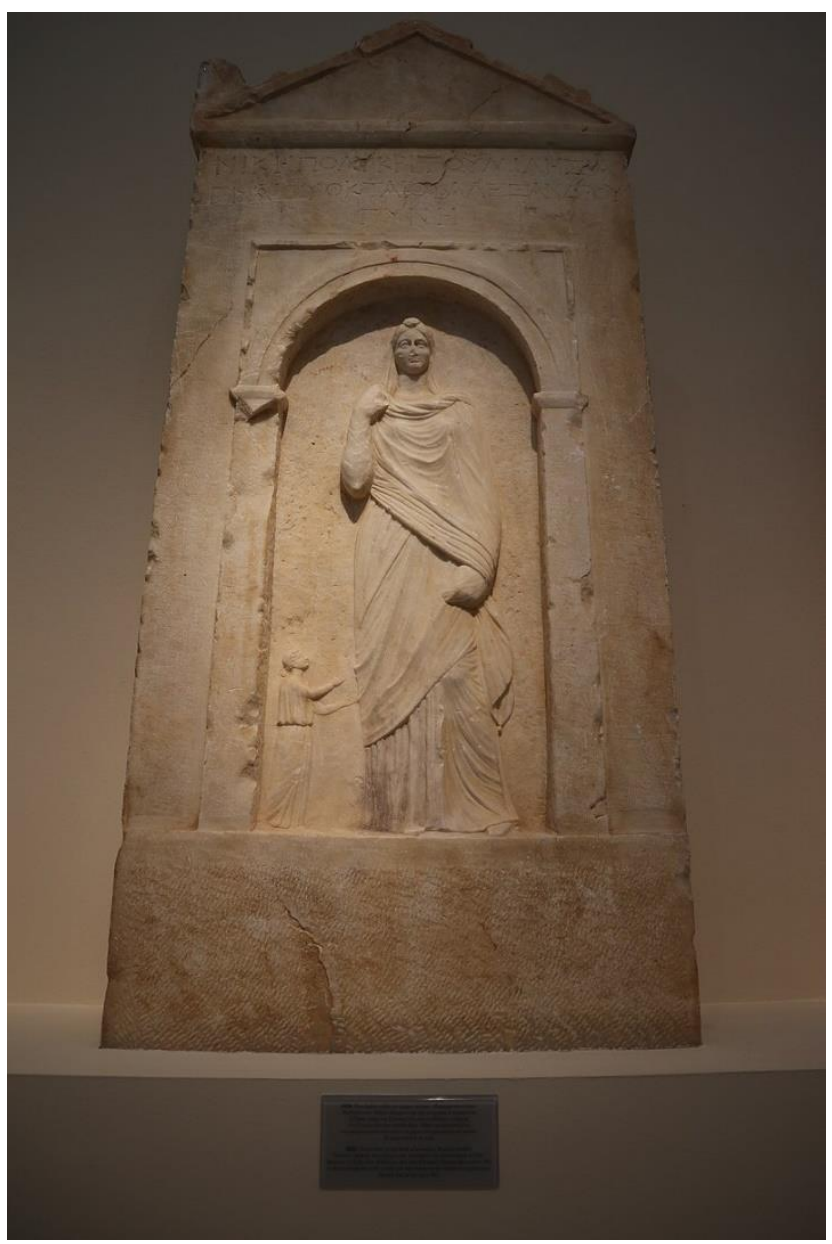

Fig. 13 Grave stele in the form of a naiskos of a deceased Athenian woman named Nike.

column. In this way Aquila uses a multivalent design to appeal to an audience in Paphlagonia and he visually inserts himself into the mix to garner a symbolic and theological legitimacy for himself.

The small naiskos in the western part of the monument and the niche of the monument also combine local and imported designs to appeal to Aquila's audience in Paphlagonia. The naiskos in the west bears resemblance to the Phrygian-inspired cult niche at nearby Kastamonu, which dates to around the same time. ${ }^{23}$ The cliffside monument concept is reminiscent of the third and second century BCE tombs of the

${ }^{23}$ Lafl $2007,57,60$. 
Pontic kings in nearby Amasya (Fig. 11). Cliff-cut tombs had a long precedence in Paphlagonia with the oldest of the nearby tombs at Salarköy (Fig. 12), Donalar and Terelik beginning construction from the end of the fifth century BCE. ${ }^{24}$ There is even evidence of a naiskos relief that was carved into the rock a short way down the road from Kuşkayas1, though this has unfortunately been destroyed by dynamite. ${ }^{25}$ The design of the niche itself is more classicizing and imported. Highly similar in form to Kuşkayası's niche is the grave stele of Nike, daughter of Polycritos of Miletos, found in Athens dating to the first century BCE (Fig. 13). They have the same plain pilasters and rounded arch, placement of the niche on a pedestal, mid relief central figure and inscription above the niche. Kuşkayası's niche design may have inspired a rock-cut niche at Paphlagonian Hadrianoupolis, and if that is the case this imitation demonstrates that the niche at Kusskayası appealed to its audience enough to warrant more designs like it. ${ }^{26}$ The niche thus incorporates an imported classicizing form and combines with the naiskos' Phrygian inspiration and a long-standing local cliff-cut tomb tradition to create a monument with a layered imperial geography.

This stylistic syncretism might indicate Aquila's position of authority in the province, essentially to convey that there is a new ruler of the region. The column is of Etruscan-type, which may be a reference to Claudius' famous interest in the Etruscans, but given the similarity with existing columns in the region, it is more likely that its design stems from local tradition going back to Salarköy. ${ }^{27}$ Like the old kings, Aquila now had a cliffside monument, but his has a classicizing and Phrygian flair and thereby a new hybrid legitimacy. The monument operates on two levels of empire: local authority and empire-wide authority. Its references to monuments in Paphlagonia and Phrygia demonstrate Aquila's command of local and regional traditions, and the imperial cult and military imagery underscore the power Aquila derived as an agent of the vast Roman Empire. These visual layers of imperial authority are another way Kuskkayası acts as an appeal to a regional audience, one which self-promoted Aquila.

In addition, Kuşkayas1 celebrates Aquila's viam et sessionem. The inscription indicates the way in which the via and sessio came about with the notable phrase montem cecidit. He felled the road out of the mountainside. The very tabula and monument celebrating the construction project is itself carved out of that same mountainside, surrounded by the chisel marks indicating the construction. In this way the monument honouring Aquila's road uses the local type of the cliffside tomb relief to celebrate the engineering project of the road by embodying its cliff-cut nature. Naturally, Kusskayas1 also celebrates Aquila's civic spending, with the standard abbreviation of D.S. P. F. (de

24 Summerer et al. 2010, 215.

${ }^{25}$ Çam et al. 2019, 204.

${ }^{26}$ Laflı 2007, 59.

27 Vanderspoel 1990, 414. 
sua pecunia fecit). In Kuskayası, Aquila combines local gods with the imperial cult, Paphlagonian, Anatolian and imported designs, and his own gens and engineering project to create a multivalent monument that appeals to a local audience in Bithynia et Pontus and advertises himself, his works and his connections to the local area and his authority under the broader Roman empire.

\section{The identity of the beheaded figure}

Scholars have not settled the question of the identity of the headless figure. Semavi Eyice labels it a statue of Claudius, Wu says that it may be either but is likely Claudius, and Marek labels it a statue of Aquila, but they offer little elaboration. ${ }^{28}$ Ultimately, considering the order in which Aquila built the two parts of the monument, the clothing and the iconographic relationship of the headless human figure, Marek's identification of the statue as Aquila is more in line with the evidence at Kuşkayas1.

Wu suggests that since the figure's head was carved separately and inserted into the cliff face, this could indicate an effort to make the face especially verisimilar as detail work would be easier to do on a head sculpted off-site. Wu also postulates that this is an anticipation that the head will be swapped out in the future, which could support the notion that this is an imperial portrait to be swapped out for the head of a new emperor. However, as Wu mentions, reusing imperial statuary carried some risk. The inscription also specifically names Emperor Claudius rather than a generic inscription to Divus Augustus, and since the inscription was cliff cut, it could not be updated or replaced to honour a new emperor (and was not, as the inscription remains unaltered). The explanation is likely a straightforward one: the delicate work of carving any face, whether a depiction of Claudius or Aquila, motivated a separate, inserted carving, and so this does not single out Claudius as the only possible subject. ${ }^{29}$

This eastern part of the monument was likely built after the western part. Its longer inscription could have used its additional space to celebrate Aquila's military triumph in $49 \mathrm{CE}$, or some other accomplishment(s). The western part of the monument likely served as a location for Divus Augustus cultic activity, as Wu argues, but even this part of the monument focuses a substantial portion of its inscription on Aquila's construction of the road. This other element of the monument is not solely focused on the cult which Aquila led but also on Aquila himself, and the same could be the case with the human figure. The beheaded statue does not inherently have to be a cult image; it could instead depict an accomplished Aquila.

It is telling that the statue wears a bimation. The Roman emperor was not recorded as having worn the bimation between the reigns of Tiberius and the philhellenic Hadrian,

${ }_{28}$ Eyice 1965, 21; Marek 2003, 56; Wu 2018, 86.

${ }^{29} \mathrm{Wu} 2018,68$. 
a time frame which included Claudius. ${ }^{30}$ Furthermore, of the 22 catalogued portraits of Claudius in Asia Minor, none of them depict him wearing a bimation. ${ }^{31}$ Of course, absence of evidence is not evidence of absence, but it does line up with the assertion that the niched figure is not Claudius. Aquila fits the mould better: he built the monument in his capacity as a private citizen, de sua pecunia fecit, and the bimation figure is dressed as such. The fact that the figure is dressed as a Greek public official indicates the statue as Aquila the "̌ $\pi \alpha \rho \chi 0 \varsigma$ more than emperor Claudius.

Furthermore, if the bimation-wearing figure is Aquila, the resulting symbolism aligns well. The human figure of Aquila stands under the standard of the imperial Eagle, and his legitimacy as governor is visually backed up by the state of Rome, its divine emperor and its military in the symbol of the eagle, the symbol which also refers to his gens. The size of the human and eagle figures is also the same, which visually connects the two, emphasizing the aquila pun. If the beheaded man is Claudius the figures do not fit together as well: the pun for Aquila would stand above and in front of the emperor, undiplomatically taking the visually superior position. ${ }^{32}$ The palm-bearing eagle which parallels Claudius' apotheosis imagery does not carry the headless figure on its back like Claudius in the cameo, another indication that the headless figure is not the emperor. As a whole, the symbolism and the relationship of the figures, as well as the figure's bimation, all point to the figure's identity as Aquila.

\section{The mutilation of the monument}

The other question central to Kuşkayas is the history of the monument's mutilation. The modern phase of destruction is most likely due to treasure hunting, and not an ideological motive. The nearby naiskos relief along the same road was dynamited by treasure hunters, establishing a context of treasure hunting damage in the area. ${ }^{33}$ Furthermore, the dynamite's target was the plain pedestal of the monument, and the boreholes concentrate on the column and tabula ansata. Those behind the destruction left the figures alone. If the motivation behind the damages was ideological, the figures would have been the primary target instead of the column and pedestal.

While the most recent stages of damage to Kuşkayas are likely the result of treasure hunters, the earlier and more targeted destruction of the heads, hands and feet suggest a different purpose for that phase of destruction. Anatolian Christians would have had an ideological reason to mutilate the polytheistic sculptures, and the head,

\footnotetext{
${ }^{30}$ Bieber 1959, 415.

31 Hildebrandt 2018 .

32 This hierarchy of space is colloquially evident in that the monument is called simply Kuskayası, rather than Adamkayasi or Kus ve Adamkayasi.

${ }^{33}$ Çam et al. 2019, 204, 206; Ertuğrul 2019.
} 


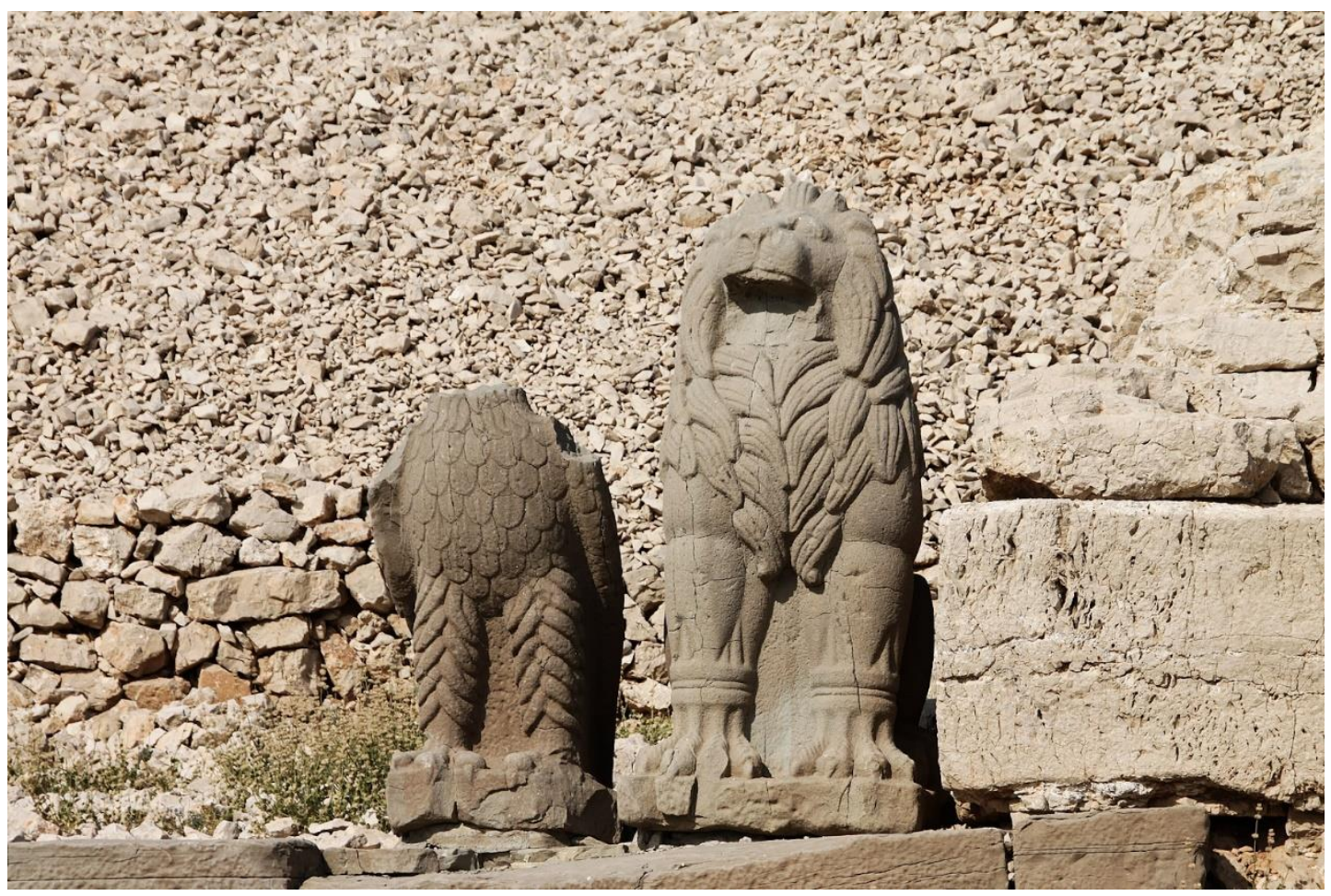

Fig. 14 Beheaded eagle at Mount Nemrut in Southeastern Anatolia, a place with many other beheaded statues. Yarl, Creative Commons, BY 2.0 License.

hands and feet of 'pagan' statues were a frequent target of Christians. ${ }^{34}$ In Late Antiquity column monuments took on a particular connotation of 'idolatry', which would have placed Kusskayası with its prominent column directly in the crosshairs. ${ }^{35}$ For the Christians, to behead a polytheistic statue erased its identity and diminished its power, and to mutilate the hands and feet of the sculptures immobilized them, reducing the chance that demonic forces might possess them and move to cause harm. ${ }^{36}$ There are many examples of this sort of destruction in Anatolia, like at Mount Nemrut in the southeast, which has beheaded eagle and human figures (Fig. 14). In Corinth, beheaded statues of Nemesis and a seated man were thrown down a well. ${ }^{37}$ The deliberate beheading and limb mutilation of Kuşkayası's figures suggests an anti-polytheistic motivation.

\footnotetext{
34 Pollini 2013, 262, 265.

35 Kristensen 2014.

36 Jacobs 2010, 284.

37 Stirling 2008, 134.
} 


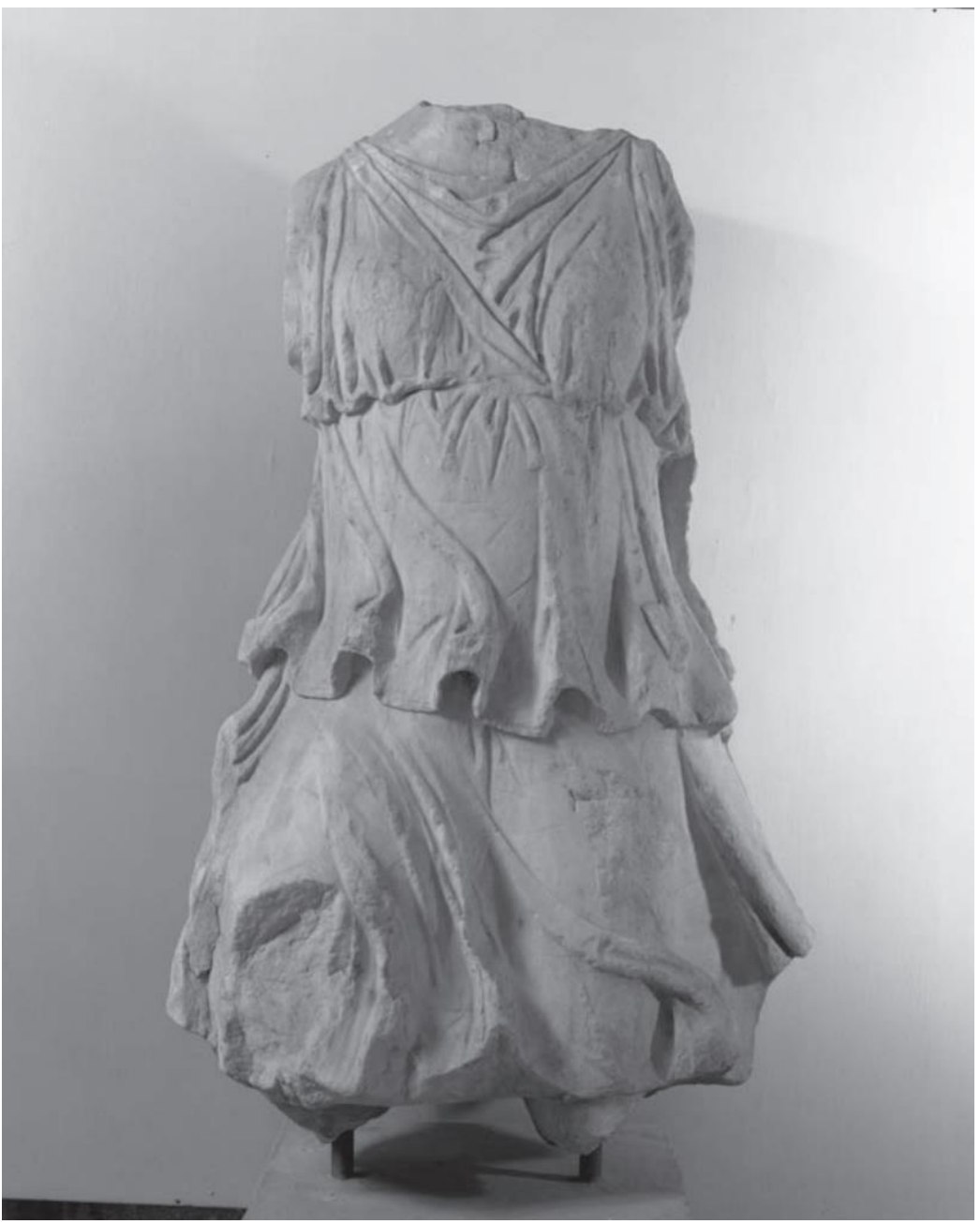

Fig. 15 Beheaded statue of Artemis from Corinth. Note the cross carved into her left thigh. Photograph: from Brown 2016, 156.

In addition to the targeted nature of the destruction, Eyice identified a cross carved into the column. ${ }^{38}$ In Late Antiquity, Christians who mutilated statues often marked them with a cross. For example, a headless, armless and broken-legged Artemis Rospigliosi was buried in a wall in Corinth with a cross chiseled into the thigh (Fig. 15). ${ }^{39}$ This sort of Christian destruction happened across the empire, from Anatolia to mutilated funeral

$38 \mathrm{Wu} 2018,73$.

39 Brown 2016, 154. 
statues on the Via Appia. ${ }^{40}$ It is likely that something similar happened to Kuşkayas1, whose easily accessible roadside location especially parallels the Via Appia's funeral statues. Though there is some difficulty in dating this iconoclastic-type phase of destruction, it is likely that the figures' mutilation was at the hands of Christians in Late Antiquity, because that was when polytheism still acted as a major rival to Christianity.

\section{Conclusion}

In sum, the 45-54 CE Kuşkayası Yol Anıtı parallels its imperial and local collage of deities with syncretistic imagery that appeals to an audience in Paphlagonia and promotes Gauis Julius Aquila as both commanding local traditions and wielding the authority of the Roman Empire. The cliff-cut monument uses the local cliff-cut monument tradition to embody and celebrate the engineering achievement of carving a paved road through a mountainside, and Aquila's civic expenditure on this impressive project. These overlapping elements illuminate the dynamic world of Roman syncretism in the art of the Black Sea coast. The headless bimation-wearing human figure likely represents Aquila himself, rather than Claudius, and the figure of Aquila stands beneath the imperial eagle standard in a way that suggests he has the military support of the state of Rome, its divine emperor, and the local god Theos Hypsistos Helios. The eagle likely also references Aquila's gens and may even suggest his placement at the top of an honorific column. Finally, the monument's first phase of destruction suggests an antipolytheistic motivation, and before it sustained modern damage from the dynamite of treasure hunters, it was probably the victim of Christian mutilation like so many other statues in Late Antiquity.

Sean Silvia

Senior undergraduate student University of Southern California ssilvia@usc.edu

40 Sauer 2003; Pollini 2013; Nixey 2017. See fig 31 of Castagnoli \& Stefani 1956. Petra, like Kuskayası, has modern phases of destruction in the form of bullet holes and damage from treasure hunters. 


\section{References}

Alper, B. \& Alper, M. 2010: 'Amasra Castle: a Small Fortified City on the Black Sea', Europa Nostra 64: 129-138.

Ando, C. 2000: 'Orbis Terrarum and Orbis Romanus', in Imperial Ideology and Provincial Loyalty in the Roman Empire, 277-335. Berkeley: University of California Press.

Bieber, M. 1959: 'Roman Men in Greek Himation (Romani Palliati) a Contribution to the History of Copying', ProcPhilAs 103(3): 374-417.

Blaylock, S. R., French, D. H., Summers, G. D., Lightfoot, C. S., Hill, Stephen J. \& Lambrianides, K. L. 1990: 'The Year's Work', AnatSt 40: 3-27.

Blaylock, S. R., French, D. H., Summers, G. D., Lightfoot, C. S., Coulton, J. J., Roberts, C. P. \& Hill, S. J. 1991: 'The Year's Work', AnatSt 41: 3-22.

Brown, A. R. 2016: 'Crosses, Noses, Walls, and Wells: Christianity and the Fate of Sculpture in Late Antique Corinth', in T. M. Kristensen \& L. Stirling (eds), The Afterlife of Greek and Roman Sculpture: Late Antique Responses and Practices, 150-176. Ann Arbor: University of Michigan Press.

Çam, F. B, Bora, A, \& Altunkayalıer, H. B. 2019: 'New Archaeological Expeditions in the Ancient City of Amastris', in G. R. Tsetskhladze \& S. Atasoy (eds), Settlements and Necropoleis of the Black Sea and Its Hinterland in Antiquity: Select Papers from the Third International Conference 'The Black Sea in Antiquity and Tekkeköy: An Ancient Settlement on the Southern Black Sea Coast', 27-29 October 2017, Tekekeköy, Samsun, 190-207. Oxford: Archaeopress.

Çorumluoğlu, Ö, Özdemir, E, \& İbrahim, A. 2013: ‘3D Digital Photogrammetric Model of Romans' "Birdrock Monument" in the Northwest Region of Anatolia', in Stratonikeia'dan Lagina'ya: Abmet Adil Tirpan Armağan, 367-373. Istanbul: Ege Yayınları.

Çorumluoğlu, Ö, Özdemir, E, \& İbrahim, A. 2014: ‘3D Photogrammetric Modeling of Cultural Heritage: Samples in Turkey', Turkish-German 3D Spatial Information Technologies Workshop. https://www.researchgate.net/publication/319181991_3D_Photogrammetric_Modelin g_of_Cultural_Heritage_Samples_inTurkey. 
Castagnoli, F. \& Stefani, B. 1956: Appia Antica: a Cura di Ferdinando Castagnoli. Milan: Domus.

Coulton, J. J. 2005: 'Pedestals as “altars” in Roman Asia Minor', AnatSt 55: 127-157.

Dessau, H. 1979: Inscriptiones Latinae Selectae, vol. 2(1), Chicago: Ares 1979 reprint.

Ertuğrul, E. 2019: 'Defineciler Mersin'de Adamkayalar'1 Parçalıyor', Arkeofili.com, March 16. https://arkeofili.com/defineciler-mersinde-adamkayalari-parcaliyor/.

Eyice, S. 1955: 'Das Denkmal von Kuşkayası bei Amasra', IstMitt 6: 109-112.

Eyice, S. 1965: Küçük Amasra Taribi ve Eski Eserleri Kılavnحu. Ankara: Türk Tarih Kurumu Basimevi.

French, D. H, Summers, G. D, Coulton, J. J, Hill, S. J \& Milner, N. 1992: 'The Year's Work', AnatSt 42: 3-14.

Hildebrandt, F. 2018: 'The Emperor Claudius in Western Asia: Portraits, Statues, and Inscriptions', in M. Aurenhammer (ed), Sculptures in Roman Asia Minor: Proceedings of the International Conference of Selcuk, 219-228. Vienna: Verlag Holzhausen GmbH.

Hill, P. V. 1989: The Monuments of Ancient Rome as Coin Types. London: Seaby.

Jacobs, I. 2010: 'Production to Destruction? Pagan and Mythological Statuary in Asia Minor', AJA 114(2): 267-303.

Kristensen, T. M. 2014: 'Using and Abusing Images in Late Antiquity (and Beyond): Column Monuments as Topoi of Idolatry', in S. Birk, T. M. Kristensen and B.Poulsen (eds), Using Images in Late Antiquity, 268-282. Oxford: Oxbow Books.

Lafl1, E. 2007: 'A Roman Rock-Cut Cult Niche at Paphlagonian Hadrianoupolis', in F. Bayram \& B. Koral (eds), T. C. Kültür ve Turizm Bakanliğ, Kültür Varlıklar ve Müzeler Genel Müdürlügü, 24. Arastırma Sonuçlar Toplantısı, 2. Cilt, 29 Mayıs-2 Haziran 2006, Canakkale, 43-66. Ankara: Kültür ve Turizm Bakanlığı.

Marek, C. 1993: Stadt, Ära und Territorium in Pontus-Bitbynia und Nord-Galatia. Tübingen: E. Wasmuth. 
Marek, C. 2003: Pontus et Bithynia: Die Römischen Provinzen im Norden Kleinasiens. Mainz am Rhein: Verlag Philipp von Zabern.

Nixey, C. 2017: The Darkening Age: the Christian Destruction of the Classical World. London: Macmillan.

Pollini, J. 2012: From Republic to Empire: Rhetoric, Religion, and Power in the Visual Culture of Ancient Rome. Norman: University of Oklahoma Press.

Pollini, J. 2013: 'The Archaeology of Destruction: Christians, Images of Classical Antiquity, and Some Problems of Interpretation', in S. Ralph (ed), The Archaeology of Violence: Interdisciplinary Approaches, 241-270. New York: University of New York Press.

Stillwell, R., MacDonald, W. L., McAllister, M. H. (eds), 1976: The Princeton Encyclopedia of Classical Sites. Princeton: Princeton University Press.

Sauer, E. 2003: The Archaeology of Religious Hatred: in the Roman and Early Medieval World. Stroud: Tempus.

Stevenson, T. 2008: 'On Dating the Frieze of Trajan's Column', MeditArch 21: 43-58.

Stirling, L. M. 2008: 'Pagan Statuettes in Late Antique Corinth: Sculpture from the Panayia Domus', Hesperia 77(1): 89-161.

Summerer, L. \& von Kienlin, A. 2010: 'Achaemenid Impact in Paphlagonia: Rupestral Tombs in the Amnias Valley', in J. Nieling \& E. Rehm (eds), Achaemenid Impact in the Black Sea: Communication of Powers, 195-221. Aarhus: Aarhus University Press.

Vanderspoel, J. 1990: 'The Etruscan Emperor Claudius', Rheinisches Museum Für Philologie 133(3): 413-414.

Wu, C. 2018: The Local Impact Of The Koinon In Roman Coastal Paphlagonia, Publicly Accessible Penn Dissertations. 3204. https://repository.upenn.edu/edissertations/3204. 